\title{
Priority targets for environmental research in the Sinos River basin
}

\author{
Spilki, FR. ${ }^{\mathrm{a} *}$ and Tundisi, JG. ${ }^{\mathrm{a}, \mathrm{b}}$ \\ aPrograma de Pós-graduação em Qualidade Ambiental, Universidade Feevale, \\ Rod. RS-239, 2755, CEP 93352-000, Novo Hamburgo, RS, Brazil \\ ${ }^{\mathrm{b}}$ Instituto Internacional de Ecologia, Rua Bento Carlos, 750, CEP 13560-660, São Carlos, SP, Brazil \\ *e-mail: fernandors@feevale.br \\ Received October 1, 2010 - Accepted October 28, 2010 - Distributed December 31, 2010
}

\begin{abstract}
The Sinos River Basin is often mentioned as a highly degraded watershed. A series of impacts on water quality, soil and air has been reported in this environment on a recurring basis over the years. This situation of environmental degradation has its origins in a process of huge economic development uncoupled from environmental conservation concerns. The intense consequent urbanization observed for the municipalities within the watershed was not preceded by urban planning proper zoning. The time has arrived for initiatives in scientific research in the Sinos River basin that are applicable to a more efficient and integrated management and recovery of the basin. In this article, a set of targets for research is suggested which the authors consider as the main priorities for the next few years, aiming for better knowledge and better management of the watershed. Some are still in course, while others have to be initiated as soon as possible.
\end{abstract}

Keywords: Sinos River basin, research priorities, sustainable development

\section{Metas prioritárias para as pesquisas ambientais na bacia do Rio dos Sinos}

\begin{abstract}
Resumo
A bacia hidrográfica do Rio dos Sinos é frequentemente citada como altamente degradada. Uma série de impactos sobre a qualidade da água, do solo e do ar tem sido relatada neste ambiente de forma recorrente ao longo dos anos. Esta situação de degradação ambiental tem suas origens em um processo de grande desenvolvimento econômico, desacoplado de preocupações com a conservação ambiental. A intensa urbanização observada para os municípios dentro da bacia hidrográfica não foi precedida pelo zoneamento e planejamento urbano adequados. É chegado o momento para iniciativas no domínio da investigação científica na bacia do Rio dos Sinos que tragam resultados aplicáveis a uma gestão mais eficiente e integrada da recuperação da bacia. Neste artigo, um conjunto de metas para a pesquisa são sugeridas como as principais prioridades para os próximos anos, visando um melhor conhecimento e uma melhor gestão da bacia. Alguns já estão em curso, enquanto outros têm de ser iniciados o mais rapidamente possível.
\end{abstract}

Palavras-chave: Bacia do Rio dos Sinos, prioridades de pesquisa, desenvolvimento sustentável.

\section{Major Research Needs for an Effective Sinos River Basin Management}

As demonstrated in the articles included in this special issue of the Brazilian Journal of Biology, there is a considerable amount of excellent research conducted on many aspects of water quality, diversity of flora and fauna, and recovery of riparian river flora in the geographical context of the Sinos River basin. Research groups working in the two main Universities in this region (namely Universidade Feevale and Universidade do Vale do Rio dos Sinos) have developed high quality research over the past years. However, there is still room for a series of research efforts which ultimately may contribute to efficient management, in tune with the sustainable development of cities in the Sinos River valley.

The integrated systemic and efficacious management of a watershed should be based on scientifically established data. The choice of the right water, soil, and air quality indicators, determined by tentative, repetitive and long term longitudinal studies, is mandatory. The indicators to be used might be the most suited to the geographical region and data collected from these species or chemicals should be repeatable, adequately addressed at the numerical level and stored in public databases, allowing easy access to this information by the scientific community, citizens 
and public administrators. Such indicators should allow a clear distinction between non-degraded, degraded and recovering areas. At the same time, data on the impact of pollutants on public health should also be harvested over time, either through secondary data analysis, or by direct research on the health of individuals in the geographical context studied.

Based on these general conceptions regarding the systemic study and monitoring of watersheds, and specific locally observed problems, the main needs for appropriate research on the environmental quality within the Sinos River basin can be suggested, as follows:

- Search and definition of effectively non-degraded areas along the Sinos River and tributaries, which may serve as "white spots" for most of the biological and non-biological parameters studied, including flora, fauna, micro-organisms and chemical compounds;

- Search and definition of the "hot-spots" for contamination and determination of the main pollution sources along the Sinos River and tributaries. These locations have to be deeply studied as suggested for the "white spots", the surrounding human and animal population should be accessed for health impacts at the phenotypic and genotypic level;

- Studies on the diversity of flora, terrestrial and aquatic fauna should be continued, at the levels of geographic distribution, species diversity (both at the phenotypic and genotypic levels), as well as physiological disorders derived from pollution exposure which have to be investigated in plants, human beings and animals (Millenium Ecosystem Assessment, 2003);

- Studies on species of fish, terrestrial animals and plants threatened by extinction should be continued as a way to better support conservation management;

- Research efforts on soil and water micro-organism diversity not available so far should be initiated;

- Research on the genotoxic effect on plants and animals found for pesticides, domestic sewage and industrial pollutants should be continued and enhanced;

- Biochemical and genetic susceptibility of individuals to situations of risk and more frequent pollutants in the region must be adequately studied and the data correlated with environmental factors found;

- Proper statistical analysis of the collected data, allowing temporal modelling and scenery prediction should be carried out. This may suitable for adoption of most correct counter measures against pollution threats to environmental quality; and

- Generation of a public database joining all the collected information, which should be continuously updated (IEEGA and São Paulo, 2009).
The constant, long-term, comprehensive and well conducted monitoring of biotic and non-biotic material collected in the points defined above, with careful laboratory analysis of classical parameters of environmental quality, coupled with advanced indicators (organic priority pollutants, endocrine disruptors, enteric viruses and emerging bacteria, trace compounds, cytotoxic and genotoxic chemicals and biologicals), can be detected and measured with more sensitive and updated methodologies. This can effectively generate an appropriate environmental risk analysis in the context of the watershed and allow the calculation of economic and social costs for remedial actions and future preventive measures to be conducted in the basin.

\section{Development of New Environmental Recovery and Preventive Technologies}

More research is urgently needed for the tannery and shoe industries located along the margins of the Sinos River. Better technologies for industry water reuse, solid residue management, and effluent treatment are indeed another major target for research. Higher rates of urban domestic sewage treatment have to achieved, preferably using modern and efficacious technologies. Promising technologies including nano-filters, and advanced oxidation are under development and may become economically viable in the next few years.

In rural areas, better and cost effective technologies for the proper management of wastes, animal sludge, sewage treatment and final destination (specially on dairy farms), rational use of pesticides and water (specially on rice production farms), should be developed and transferred to farmers together with environmental education (UNEP, 2008)

Regulatory frameworks, legislation and other legal aspects related to the management and protection of the environment should be studied and discussed at the local level, as a solution in the future to the already serious conflicts over water and land use, which now involve the government, industry, rice farmers and non-governmental organizations for environmental protection.

\section{Conclusions}

The management of complex watersheds such as the Sinos River basin needs the integration of three basic processes: first, a continuous monitoring process in order to collect information on the functioning and the dynamic interactions of terrestrial/aquatic ecosystems; second, a permanent integration is necessary of analysis and synthesis of water availability and water demand and the integration of atmospheric, surface and ground water management; and third, the establishment of a consolidated process of water governance by the watershed communities (Nakagami, 1989; Tundisi, 1990). A strategic concept of basin-wide economic development coupled with environmental conservation, recovery of ecosystems and evaluation of environmental services of terrestrial and aquatic ecosystems 
is essential (Constanza et al., 1997; Millenium Ecosystem Assessment, 2003). The formulation of action programs, the transference of knowledge to the management process and the adoption of a basis of science and technology in the management process (IEEGA and São Paulo, 2009) is another relevant step towards water governance.

Public participation in the governance process is also another step forward to promote good governance of the watersheds (sub basins and the Sinos river watershed). To be effective the general public needs to be informed and dissemination of information about the state of the watershed, its main critical problems and ways to solve them should be part of the effort of universities, research institutes and research workers. Today, the idea of translational ecology (Schlesinger, 2010) is fundamental in promoting a better and effective use of scientific knowledge for public policies and public participation.

In the $21^{\text {st }}$ century, the promotion of better scientific understanding of the environmental process has to be coupled with public participation, "environmental governance" and permanent information about the "state of the environment" to the general public, environmental managers and administrators. The use of technological alternatives ("low-tech" - "eco-tech") is recommended to lower costs of interventions (Somlyody and Varis, 2006) and to promote public participation in a more effective way (Tundisi and Matsumura-Tundisi, 2010, in press; UNEP, 2008).

It is expected that this first volume on the Sinos River watershed is the necessary diagnosis and synthesis at the present stage of the research and management perspectives. Future volumes will certainly describe advances and critical steps to be taken in the introduction of new technologies and perspectives for water governance.

\section{References}

CONSTANZA, R., D'ARGE, R., DE GROOT, R., FARBERPARALLEL, S., GRASSO, M., HANNON, B., LIMBURG, K., NAEEM, S., O'NEILL, RV., PARUELO, J., RASKIN, RG., SUTTON, P. and VAN DEN BELT, M., 1997. The value of the world's ecosystem services and natural capital. Nature, vol. 387, p. 253-259.

Instituto de Ecologia e Gereciamento Ambiental - IIEGA and São Paulo (Município). Secretaria de Vigilância do Meio Ambiente - VMA-PMSP, 2009. Manual de gerenciamento de bacias hidrográficas. São Paulo: Prefeitura Municipal de São Paulo. 134 p.

Millenium Ecosystem Assessment, 2003. Ecosystems and human well being. A framework for assessment. Washington: Island Press. 236 p.

NAKAGAMI, K. 1989. A Strategic Concept of River/Lake Basin Management and Planning. In Second Expert Group Workshop on River/Lake Basin Approaches to Environmentally Sound Management of Water Resources: Focus on Policy Responses to Water Resources Management Issues and Problems. Bangkok and Hat Yai, Thailand. p. 9-10.

SCHLESINGER, WH., 2010. Translational ecology. Science, vol. 329, p. 609. Editorial.

SOMLYODY, L. and VARIS, O., 2006. Freshwater under pressure. International Review for Environmental Strategies, vol. 6, no. 2, p. 181-204.

TUNDISI, JG. and MATSUMURA TUNDISI, T., 2010. Água no século 21. São Paulo: Oficina de Textos. 250 p. In press.

TUNDISI, JG., 1990. Ecology and development: perspectives for a better society. Physiology \& Ecology Japan, vol. 27, p. 93-130. Special number.

United Nations Environment Programme - UNEP, 2008. Every drop counts. Environmentalle sound Technologies for urban and domestic water uses efficiency. New York: IETC. 197 p. 